\title{
Contribution of the Principal Supervision and Work Motivation on Teacher Performance at Public High School in Barito Kuala District
}

\author{
Muhammad Rahmatullah *, Muhammad Saleh, Metroyadi
}

Graduate of Educational Management, Universitas Lambung Mangkurat, Banjarmasin, 70123, Indonesia

\begin{tabular}{l|l}
\hline \multicolumn{1}{c|}{ A R T I C L E I N F O } & \multicolumn{1}{c}{ A B S T R A C T } \\
\hline Article history & $\begin{array}{l}\text { The purpose of the research is to know the Principal's supervision contribution and } \\
\text { work motivation toward the teachers' performance at the public of Senior High } \\
\text { School at Barito Kuala, District. The research population is public teachers at the } \\
\text { Received: June } \\
\text { Revised: August }\end{array}$ \\
$\begin{array}{l}\text { Secepted: December } \\
\text { Keywords: The Principal } \\
\text { Supervision, work } \\
\text { motivation, teachers } \\
\text { performance }\end{array}$ & $\begin{array}{l}\text { by determining sample to each school in a proportional manner and found as much } \\
\text { as I45 teachers. For data collection is conducted by a questionnaire. And the } \\
\text { questionnaire validity trial is conducted by the corrected item - Total correlation. A } \\
\text { reliability trial is using Cronbach's Alpha (a). Data Analysis is taking simple } \\
\text { regression and double technique. The data's outcomes are: (I) significantly, there is } \\
\text { the Principal's supervision contribution toward teachers performance at Senior High } \\
\text { School in Barito Kuala, with determination value 66,I\%; (2) There is a work } \\
\text { motivation contribution towards teachers performance at public of Senior High } \\
\text { School in Barito Kuala, significantly with determination value 65,6\%; (3) And so, } \\
\text { with significantly there is a Principal's supervision contribution and work motivation } \\
\text { toward teachers performance at Public of Senior High School in Barito Kuala } \\
\text { District, in the manner of determination value 74,8\% }\end{array}$ \\
\hline
\end{tabular}

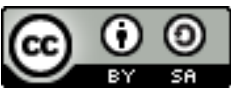

(C) 2019 The Authors. Journal of K6, Education, and Management (j-K6EM). ISSN: 2580-2135. Published by Graduate Program of Educational Management, Universitas Lambung Mangkurat, Banjarmasin 70123, Indonesia. This is an open-access article under the CC-BY-SA license.

*Correspondence: Muhammad Rahmatullah; Email: mrahmatullah73@gmail.com 


\section{Introduction}

Development or foundation in education sector is effort to educated the nation existence to improve the quality of Indonesian people devout, obedient and have a certain lofty characters, who master the educations, high technology, and art well to bring into quality or create the community and society go forward, equitable, prosperous and civilized or polite based on the five principles of Indonesia (Pancasila) and constitution (UUD 1945). The quality of education as one of the pillars of human resource development is strategic for national development. That is, the future of the nation is very dependent on the quality of today's education, and quality education will emerge if school level education is also of high quality.

To ensure the expansion access, quality upgrading, relevance, good government, and education accountability to overcome the challenges and deviances according to the demand of local life alteration, national and global are needed empowerment to improve the teacher's quality planned, directed and guided continuously. The quality of education improvement based on a lot of things, especially and most important for teacher's grade, so, both quality and teacher's grade are determining for education success, even though there isn't the only one factor determinate but so many things support it, such as education system, school management, curriculum, through a medium and education infrastructure.

Related to the teachers quality is not released from the process of teachers performance or teachers achievement in implementation of their main assignments at school, which are the teachers must have both the high loyalty and commitment for teaching activity, and prosecuted to have the skill to master the subject and how to develop instruction as good as possible, and so the teachers asked to have noble personality and become leaders for their students, must have strong pretension to lead the students to overcome and finish their education process at school. The teacher's assignment is not only to make the students success to get both pieces of knowledge and practice only but however, the teachers have to think about students a good attitude and behavior.

Simamora (1997) said, that achievement or performance is mean by accomplishment to the rule of work regulation only that immediately can be reflected from the good output of its quality and identity. The value of the teacher's competence test (UKG) showed that the Indonesian teachers just success to get 44,5 or it's still in the low of the national average. At this moment, the total of teachers who follow of teacher's competence test (UKG), are 243.619 persons with their score 44.55. In the fact that none of them get a maximum score of 100. The highest score of the teacher's competence test (UKG) is only 91.12. For the implementation of the Teacher Competency Test (UKG) carried out for high school teachers in Barito Kuala district in 2015, the average score of 59.47 was achieved, which was still below the average score of the South Kalimantan province of 61.74 and the national average value of 63.09 , then for the whole teacher at all levels of the UKG result obtained by Barito Kuala district obtained an average score of 56.83 while the average value of the province of South Kalimantan was 56.93.

When looking at the achievement of UKG results in Barito Kuala district it means that the teachers at the high school level in Barito Kuala district are still not maximal in carrying out the main tasks and functions of the teacher according to their competencies, including pedagogical competencies, personality competencies, social competencies, and professional competencies. The implementation of competencies for a teacher is a description of the teacher's performance in carrying out his duties as an educator based on the ability of the teacher in terms of knowledge, attitudes, skills, and motivation in work.

The description of the author's observation as the head of the state High School in Barito Kuala is the lack of teachers in mastering the character of students, mastering learning theory and the principles of educational learning, curriculum development, developing potential student, high work ethic and responsibility, being inclusive, acting objectively, mastering the material, concept and patterns of thinking that support maple who are taught and develop professionalism through reflective actions.

The teacher's performance can be looked at of its quality, affectivity, productivity, efficiency, innovation, the life quality of its performance and so of their moral performance. The teacher's assignment as the organizer of the teaching and learning activity process in the classroom is not as easy as regarded, but here the teachers are very important and how to become central. So, every one of the teachers here is needed to have ideal a good personal psychology characteristic as ruled and regulated, then, what the teachers have to do is the teacher's competency and professional that can differ the teacher's 
profession and the others. The teachers have too many assignments that are related to the official duty or out of it in the type of dedication. Teacher performance is the whole of the teacher's effort to achieve the learning process

The role of principals is to manage quality educational institutions according to predetermined standards (Metroyadi, 2015), namely by providing guidance, direction, creation, supervision and estimating them to do their job correctly. Therefore, the principal through leadership learning can motivate and empower teachers to create good work motivation and be able to act as teachers who have a professional attitude besides the teacher himself who can improve the quality of his work (Rizqan, 2019). Supervision is also important to do by the principal because it can assist teachers in schools to jointly realize the school's goals and national educational goals (Rijani et al., 2018).

Mantja (2007) explained that the supervision or professional creation is assistance or service to the teachers, to know how to improve and develop the ability in the learning process. Mulyasa (2005) said, that supervision is a part that cannot be separated from all of the education administrations processes that tended for developing performance effectively of school personality which is related to the main tasks of education. Instead, the factor of the Principal supervision influences the teachers' performance is work motivation. There was an indirect influence of the supervisor's supervision on teacher behavior through teacher work motivation (kusrini et al., 2018).

Motivation is a power that can make someone do better things than before, and it can grow from oneself or it's can arise from the other stimulation. According to conceptual work, motivation is one factor that determines the teacher's performance. Great or small the side effect of motivation towards someone's performance is depending on how great motivation intensity is given. Proposed, there are two kinds of motivations, both are intrinsic and extrinsic motivations. The main problem raised in this study is the focus on determining the contribution to the performance of the Principal's supervision of the teacher's performance; understand the contribution of work motivation to teacher performance and know the contribution of principal supervision, and work motivation and teacher performance.

Based on the scope of the research and the formulation of the problem above, the assumptions made in this study can be made as follows:

First, the Principals of senior high school in all District of Barito Kuala have different abilities in supervising teachers in their schools.

Secondly, teachers at the state of senior high school at Barito Kuala District have been supervised by the school principal.

Third, state high school teachers throughout Barito Kuala District have different work motivation, because the work motivation of teachers is very much a factor that influences both external and internal factors. Fourth, every state of senior high school in Barito Kuala District has a different performance.

The hypotheses of this study as follows:

1) There is contribution supervision of the principle on the performance of teachers in high school in Barito Kuala District,

2) There are contribution motivation to work toward teacher's performance at high school in Barito Kuala District was contributed

\section{Methodology}

This study uses a quantitative research approach and correlational in nature because it examines and solves the problems it currently faces and has the aim of obtaining information about the presence or absence of a relationship between two or several variables about a particular situation. The objectivity was obtained among others, through the use of instruments that have been tested for validity and reliability. Two independent variables were determined, namely principle supervision (X1) and work motivation of (X2), and one of the dependent variables. Teachers' performance (Y), The two independent variables with systems as follow: 1) related variable between $\mathrm{X} 1$ to $\mathrm{Y} ; 2$ ) related variable $\mathrm{X} 2$ to $\mathrm{Y} ; 3$ ) related variable between $\mathrm{X} 1, \mathrm{X} 2$ to $\mathrm{Y}$.

The method used in this research is a survey method with a quantitative approach. To collect data it used a questionnaire technique for data collection or questionnaire with a Likert scale. And to supervise the Principal is used the correct indicator as Sujana (2011) said that aspect of assignment implementation, creation, assessment, and teacher's professional in : (1) planning of learning, (2) learning implementation, (3) taking of assess learning, (4) guiding and drill the students, (5) implementation of assignment addition according to the teacher's main assignment. The are several instruments to measure the teacher's performance: 1 . Internal motivation, includes: a) teacher's responsibility to 
implement his assignment, b) implement assignment with a clear target, c) has specific purpose and challenge, d) there must be a feedback on what has done, e) always cheerful to work, e) effort to be better than the other, f) to show achievement to things have done.2. external motivation, including a,) always exertion to fulfill a life necessity, b) always cheerful to get accolade to what have done, c) working hard to get the incentive, d) working by hard to get attention from a superior. The are several instruments and indicators to measure the teacher's performance: 1) mastering the student's characteristic, 2) mastering of learning theory, 3) curriculum development, 4) educated and fun learning, 5) development of student's potential, 6) communication building, 7) assessment and evaluation, 8) controlling based on the rule, social, law and national culture,9) to show a good attitude, 10) responsible, hard work to become teacher, 11) must be inclusive, objective and not discriminative, 12) get communication between teachers, parent and the others, 13) mastering the subject as good as possible, fringe, tassel and its rule, 14) professional development with the reflective action.

Before using, the research questionnaire has been validity experimented and its reliability using the corrected item formula - Total Correlation and Alpha Cronbach formula. But for data processing, it is using descriptive and inferential analysis. This research is conducted to public senior high school in Barito Kuala District, South Kalimantan in the amount of 227 persons as population, and chosen 145 respondents as a sample by using Slovin formula (Riduwan, 2005). The sampling technique that the writer uses here is the proportional technique random. Requisite analysis experiment is done before the hypothesis, there are included: normality test, homogeneity experiment, linearity experiment, multifarious test, and heterogeneous experiment. Technique used in hypotheses test: 1) The first and the second hypotheses are examined by correlation and simple regression technique, 2) The third hypotheses is examined by doubled correlation and regression, and then to be continued by sense test of $\mathrm{t}$, $\mathrm{f}$ test, and correlation coefficient test, but for data processing and counting by using statistics analysis program of IBM SPSS statistics 25.

\section{Findings and Discussion}

First, The Principal's supervision at state Senior High School in Barito Kuala, South Kalimantan based selection of respondents note the value data obtained by respondents to supervise principals have a minimum value of 40 , the maximum value of 104 , the average value of data 72.72, standard deviation 15.969, variance of 254.996 , and range of 64 . For the results of the calculation of the respondent's answer score, the ideal average of 69.00 and the ideal standard deviation of 15.55 are obtained in the following table:

Table 1. Data of the School Principal Supervision Score Group

\begin{tabular}{cccc}
\hline Interval & $\begin{array}{c}\text { Freque } \\
n c y\end{array}$ & $\begin{array}{c}\text { Percenta } \\
\text { ge }\end{array}$ & $\begin{array}{c}\text { Classificat } \\
\text { ion }\end{array}$ \\
\hline$>84,33$ & 32 & $22 \%$ & High \\
$53,67-$ & 96 & $66 \%$ & Is being \\
84,33 & 17 & $12 \%$ & Low \\
$<53,67$ & 145 & $100 \%$ & \\
Score & 145 & \\
\hline
\end{tabular}

So that the average score of the respondent's answer for the supervising variable of the principle including in the category is being based on most of the respondents amounted to $96 \%$ of people or 66 of respondents. It can be explained that the supervision carried out by the principle in State High School in Barito Kuala District, South Kalimantan Province is still not optimal. So that thus proves that supervision done by principle can make a positive contribution to improving teacher performance at school. Second, the work motivation of teachers in State High School in Barito Kuala District of South Kalimantan Province is seen from the date of respondent's answers to work motivation having a minimum value of 40, a maximum value of 105 , an average of 73.62, a standard deviation of 16,625, variance amounting to 276,376 , and a range of 65 . For the results of the calculation of the respondent's answer score, the ideal average is 78.00 and the ideal standard deviation of 17,55 , the following table is obtained:

Table 2. Group Data on Work Motivation Scores

\begin{tabular}{cccc}
\hline Interval & $\begin{array}{c}\text { Freque } \\
n c y\end{array}$ & Percentage & $\begin{array}{c}\text { Classific } \\
\text { ation }\end{array}$ \\
\hline$>95,33$ & 14 & $10 \%$ & High \\
$60,67-$ & 94 & $65 \%$ & Is being \\
95,33 & 37 & $26 \%$ & Low \\
$<60,67$ & 145 & $100 \%$ & \\
Score & 145 & \\
\hline
\end{tabular}

So that from the average score of the respondent's answer for the teacher's work motivation variables included in the moderate category based on the number of respondents the most numbered 94 people or $65 \%$ of respondents. This can be explained that the work motivation that is owned by the teacher in the State High School in Barito Kuala District, South Kalimantan 
Province is still not optimal. In carrying out work the role of motivation is very important, people will work harder and diligently if they have high motivation in themselves.

The third, teacher's performance at public Senior High School in Barito Kuala District of South Kalimantan, based on the result of the respondents score obtained a minimum value of 45 , the maximum value of 100 , an average of 77,43 , with deviation standard as much as 14,870, with 221,10 variant, and with 55 range. To determine the position criteria of each variable determined based on the provisions of the conversion convers stipulation value of teacher's performance to a mark grade, the following table is obtained:

Table 3. Group Data on Teacher Performance Score

\begin{tabular}{cccc}
\hline Interval & $\begin{array}{c}\text { Frequen } \\
\text { cy }\end{array}$ & $\begin{array}{c}\text { Percent } \\
\text { age }\end{array}$ & $\begin{array}{c}\text { Classificatio } \\
n\end{array}$ \\
\hline $91-100$ & 34 & $23 \%$ & Very good \\
\hline $76-90$ & 47 & $32 \%$ & Well \\
\hline $61-75$ & 38 & $26 \%$ & Enough \\
\hline $51-60$ & 19 & $13 \%$ & Is being \\
\hline$\leq 50$ & 7 & $5 \%$ & Less \\
\hline Score & 145 & $100 \%$ & \\
\hline
\end{tabular}

So that 7 persons or $5 \%$ of respondents who get low performance value, 19 persons or $13 \%$ of respondent who get medium performance value, 38 respondents or $26 \%$ who get enough value, as much as 47 persons or $32 \%$ respondents who get a good performance value and 34 persons or $23 \%$ respondents who get excellent value. At the end of those all, the teacher's performance is in a good category, that's based on the values are taken by respondents after taking a percentage to mark grade and it got the most respondents in the amount of 47 persons or $32 \%$ with the good category. So, it can be explained that the performance of teacher's value at the state of senior high school in Barito Kuala District of South Kalimantan does not maximum yet but can be improved.

Conducting the calculation or computation in regression and correlation analysis, trial of regulation analysis must be held previously towards the variable of the Principal's supervision (X1), work motivation (X2) and teacher's performance (Y). Regulation trial is (a) normality test, (b) homogeneity test, (c) linearity test, (d) multi linearity test, (e) heterogeneity test.
The first, normality test, the research is utilizing the Kolmogorov-Smirnov test. The value determination here is based on probability value $>0,05$ and can be concluded that the research data in a normal distribution. Calculation of data normality test in this research can be looked at a table below:

Table 4. The Output of Data Normality

\begin{tabular}{|c|c|c|c|c|}
\hline No & Var. & Sig. & Criteria & $\begin{array}{c}\text { Explanat } \\
\text { ion }\end{array}$ \\
\hline 1 & $\mathrm{X} 1$ & 0,051 & $0.051>0,05$ & Normal \\
\hline 2 & $\mathrm{X} 2$ & 0,088 & $0,088>0,05$ & Normal \\
\hline 3 & $\mathrm{Y}$ & 0,069 & $0,069>0,05$ & Normal \\
\hline
\end{tabular}

conducted to know the variant sample category taken from the same population. The research in this part is utilizing Levene Test (L), based on significant test 0,05 , if the significant value $>0,05$, so the variant of each sample is same (homogeneous), if the significant value $<0,05$, so the variant of each sample is different (Not homogeneous). Here is significant value based on homogeneity test $=0,450>0,05$ so the variant of every sample is homogeneous.

Table 5. The Outcome of Homogeneity Test

\begin{tabular}{ccccc}
\hline No & Var. & Sig. & Criteria & $\begin{array}{c}\text { Explanat } \\
\text { ion }\end{array}$ \\
\hline 1 & X1_X & 0,450 & $\begin{array}{c}0,450> \\
0,05\end{array}$ & $\begin{array}{c}\text { homogene } \\
\text { ity }\end{array}$ \\
\hline
\end{tabular}

The third, linearity test, to know is a regression has the quality of linear or no. The formula used here is variable ANOVA X and Y. Decision based on linearity significant value 0,05 means have the linear quality, and the value for linearity significant 0,05 means have no linear quality. It wants to know the relation between $\mathrm{X} 1$ towards $\mathrm{Y}$ and $\mathrm{X} 2$ towards $\mathrm{Y}$. Here is the table of linearity test result below:

Table 6. The Outcome of Linearity Test Data

\begin{tabular}{ccccc}
\hline No & Var. & Sig. & $\begin{array}{c}\text { Criter } \\
i a\end{array}$ & $\begin{array}{c}\text { Explanat } \\
\text { ion }\end{array}$ \\
\hline 1 & X1 to $\mathrm{Y}$ & 0,000 & $\begin{array}{c}0,000 \\
<0,05\end{array}$ & Linear \\
2 & X2 to $\mathrm{Y}$ & 0,000 & $\begin{array}{c}0,000 \\
<0,05\end{array}$ & Linear \\
\hline
\end{tabular}

The fourth, the purpose of multi linearity test to know whether the regression model found the strong correlation between statistical Variable $\mathrm{X}$ to Y. Multi linearity test can be seen from the calculation of table Coefficients of the statistic, based on a certain determinate decision as follows: 1) looking at tolerance outcome $>0,10$ it avoids multi linearity, tolerance value $<0,10$ may raise 
multi linearity, or 2) by looking at VIF (Variance Inflation Factor) value, for VIF value 10,00 will avoid Multi linearity. From the calculation of Multi linearity test in this research can get the outcome of the list below:

Table 7. The Outcome of Multi Linearity Test

\begin{tabular}{cllll}
\hline \multirow{2}{*}{ No } & \multicolumn{2}{c}{ Value } & Criteria & $\begin{array}{c}\text { Explanatio } \\
n\end{array}$ \\
\hline \multirow{2}{*}{1} & Tolera & 0,4 & $0,422>0$, & Not multi \\
& nce & 22 & 10 & linearity \\
2 & \multirow{2}{*}{ VIF } & 2,3 & $2,731>$ & Not multi \\
& & 71 & 10,000 & linearity \\
\hline
\end{tabular}

The fifth, heterogeneity test is the classic assumption test in regression analysis that purposed whether in regression model the difference between the variance value of observation one residue and the other. Decisionbased on significant value $>0,05$, means heterogeneity does not happen, but for significant value 0,05 means heterogeneity happens. Here is the table of the result got from the heterogeneity test of the research below.

Table 8. The Outcome of Heterogeneity Test

\begin{tabular}{|c|c|c|c|c|}
\hline No & Var & Sig. & Criteria & Explanation \\
\hline 1 & $\mathrm{X} 1$ & 0,000 & $\begin{array}{c}0,000< \\
0,05\end{array}$ & heterogeneity \\
\hline 2 & $\mathrm{X} 2$ & 0,231 & $\begin{array}{c}0,231< \\
0,05\end{array}$ & $\begin{array}{c}\text { Not } \\
\text { heterogeneity }\end{array}$ \\
\hline
\end{tabular}

This research, hypotheses testing is conducted by the correlation coefficient, signification level, determination coefficient, and regression analysis. Based on statistic result calculation for correlation analysis, simple regression and double regression are significant and precious positive, here are the exegesis and clarification of it. The first, the contribution of the Principal supervision towards teacher's performance is in the amount of 0,661 or $66,1 \%$, followed by its rest $33,9 \%$ determinate by the other statistical variable out of the Principal's supervision. The result of research about the statistical variable of the Principal's supervision gave a positive contribution and significant toward the teacher's performance. Here is the list taken from the regression as graft $\mathrm{Y}=22,379+0,757 \mathrm{X} 1$ it can be interpreted that without statistical variable of the Principal supervision so the result of the teacher's performance will be 22,379 , but if the Principal's supervision is conducted or held, so the teacher's performance is increased in the amount of 0,757 , of the teachers performance. Based on the data to do the analysis with the obtained value determination supervision of the school principal to the teacher's performance as much as $66,1 \%$ by all means that he Principal's supervision can support the teacher's performance to improve their ability in the teaching and learning process. The outcome achievement is tightening with the opinion of several experts, such as Mulyasa (2005) explained that supervision is a part that can't be separated from all processes of education administrations which is pointed or tended mainly to develop affectivity of school personal performance.

The second, the contribution of work motivation toward teacher's performance as much as $34,4 \%$ determinate from the other statistical variable out of work motivation. The output of the research mentioned, the statistical variable of work motivation gives a positive contribution and significant toward the teacher's performance. The regression can be looked at to the list as given below $\mathrm{Y}=24,101+0,724 \mathrm{X} 2$ that can be interpreted that without the statistical variable of Principal supervision so the result of the teacher's performance will be 24,101 , but more Principal's supervision conducted is more increased 0,724 of teachers performance shown. From the data above it can take the analysis by taking the contribution of the Principal's supervision toward teacher's performance as much as $65,60 \%$ by means that the The third, the contribution of the Principal's supervision and teachers' work motivation in accordance with simultaneous toward teacher's teaching performance as much as 0,748 or $74,80 \%$ followed by its rest $25,20 \%$ determinate by the other statistical variable out of the Principal's supervision of the teacher's performance. Here is the list taken from double regression $\quad \mathrm{Y}=15,853$ $+0,435 \mathrm{X} 1+0,406 \mathrm{X} 2$, can be interpreted that without statistical variable of Principal supervision and work motivation so the result of teacher's performance will be 15,853 , but if the Principal's supervision is conducted or held, so the teacher's performance is increased in the mount of 0,435 , more increase of a work motivation, so the statistical variable of teacher's performance up to 0,406 if it compares with each of variable, means that increasing of teacher's performance is not only by giving the Principal's supervision but teacher's performance, improving of Principal's supervision must be gathered with teacher's performance. So, in this research can be concluded that the Principal's supervision and work motivation is influential toward the teacher's performance. Furthermore, by Principal's supervision and high work motivation are improved the teacher's performance. 
Extrinsic motivation is motivation because of individual stimulation from outside, with several indicators: (1) always trying to make ends meet, (2) cheerful to get an appreciation for what has been done, (3) working hard to get incentives, (4) and to get the attention of superiors.

Supervision rights of the principal and high work motivation will result in better teacher performance. Principal supervision activities and work motivation influenced by psychologists on teacher performance in teaching. Teachers who have been supervised by the Principal correctly and continue and are highly motivated so that they will work professionally and seriously that can get their performance promoted. But if the teachers do not get the supervision of the Principal and the teachers have low motivation means the teachers are unprofessional and lack the desire, so that they can make their achievements low. The reality experienced by the researcher shows that the correlation between school supervisors and school principals is still not as expected as they should be. The effort to improve the quality of education through supervision services from school supervisors, school principals, and teacher performance can be improved so as to improve the quality of the process and learning outcomes in the classroom (Aslamiah, 2014). Teacher performance is an important element in education, in addition, it is also a determinant of the high and low quality of education. Teacher performance is carried out by the teacher in carrying out the duties of a teacher as an educator. The teacher is the main factor in the education process, while the education facilities are complete and sophisticated.

\section{Conclusion and Recommendation}

The Principal supervision at state Senior High School in Barito Kuala District of South Kalimantan is in the medium category. Those are based on the average result of respondents' responses for a statistical variable of the Principal's supervision with the most respondents in the medium category. Teachers' work motivation at public Senior High School in Barito Kuala District of South Kalimantan is in the medium category. Those are based on the average result of respondents' responses to the variable of the teachers' performance with the most respondents in the medium category. Teachers' performance at public Senior High School in Barito Kuala District of South Kalimantan is including in good category. Those are based on the average result of teachers' performance from respondents for a variable of the teachers' performance with the most respondents in the good category. There was a significant contribution between the Principal supervision and teachers' performance at state Senior High School in Barito Kuala District of South Kalimantan in the mount of $66,10 \%$. By means, the level of teachers' performance is $66,10 \%$ following by the Principal's supervision. There was a significant contribution between the teachers' performance and teacher's teaching performance at public Senior High School in Barito Kuala District of South Kalimantan in the amount of $66,60 \%$. By means, the level of teachers' performance is $65,60 \%$ with work motivation. There was a significant contribution between the Principal's supervision and work motivation coincide toward teachers' performance at state Senior High School in Barito Kuala District of South Kalimantan in the amount of 74,80\%. By means, the level of teachers' performance can be explained through supervision conducted by the Principal and teachers' performance itself.

Intrinsic motivation is motivation that does not require external stimulation because it has originated from the individual himself, by way of compliance with his needs, followed by several indicators: (1) The responsibility of the teacher to carry out their tasks, (2) how to carry out these tasks with targeted targets clear and explicit, (3) have certain goals and challenges, (4) Feedback about what has been done, (5) must be cheerful to do the tasks, (6) Always try to be very good, (7) must be an achievement which stands out in what's happening. All Principals of state of Senior High School in Barito Kuala District of South Kalimantan have to more supervise to the teachers continuously, especially how to make and arrange a good Lesson Plane (RPP), how to arrange a good step and teaching action, arrange a good syllabus, classroom condition, do their addition assignments as the vice of Principal, such as the chief of library and the other tasks. At least the supervision conducted twice a year based on the school condition. All of teachers at public Senior High School in Barito Kuala District of South Kalimantan have to improve themselves of work motivation that could established whether comes from inside motivation or out, especially how to establish of high responsibility to do their assignments as good as possible, doing the tasks with limit and explicit target and always cheerful to have work and effort to become better than the other. So it can improve their creativity, innovative and working hard to get the maximum performance. The Principal and the teachers are arranging together with the detailed program for improvement activity toward the outcome found of teachers performance assessment to make better for next, and can improve the value report of 
employees target performance and estimation employees achievement every year., Here for the next researcher is suggested to research the other variable that can give positive profit or contribution toward the teacher's performance.

\section{Aknowledgement}

We express our gratitude to the supervisors and Board of Examiners who have provided a highly useful command. Thank you also to the Headmaster and staff who have provided the opportunity to conduct research. Additional Acknowledgments to the editorial of the j-k6em journal and all parties who have helped in the publication of this scientific work.

\section{References}

Aslamiyah. (2014). Strategi Pembelajaran . Banjarmasin: Universitas Lambung Mangkurat.

Kusrini, L., Suriansyah, A., Saleh, M. (2018). Pengaruh Supervisi dari Supervisi Akademik dengan Komitmen Kerja Guru Terhadap kinerja Guru pada SMA Negeri di Kota Banjarmasin. European Journal of Educational Studies, Volume 5.

Mantja, W. (2007). Etnografi: Desain Penelitian Kualitatif Pendidikan dan Manajemen Pendidikan. Malang: Elang Emas.

Mulyasa, E. (2005). Menjadi Guru Profesional. Bandung: PT. Remaja Rosdakarya.

Riduwan. (2005). Skala Pengukuran VariabelVariabel Penelitian. Bandung : CV. Alfabeta.

Rijani, A., Saleh, M., \& Metroyadi. (2018). Korelasi Antara Supervisi Akademis Kepala Sekolah, Komitmen Guru, Moral Guru dan Kinerja Guru SMP Negeri di Kabupaten Tapin. Jurnal Penelitian \& Metode IQSR dalam Pendidikan (IQSRJRME), 8(6): 1-6.

Simamora, H. (1997). Manajemen Sumber Daya Manusia. Yogyakarta: STIE YKPN. 